\title{
Imagens de Índios do Brasil: O Século XVI
}

\section{MANUELA CARNEIRO DA CUNHA*}

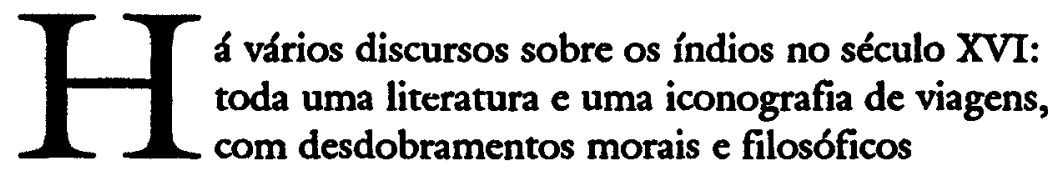

firma seus cânones ao longo do século; um corpus legiferante e de reflexáo teológica e jurídica elabora, passada a era do escambo, uma ordenação das relaçóes coloniais; paralela à conquista territorial, a conquista espiritual, por sua vez, se expressa sobretudo em um novo gênero, inaugurado pelos jesuítas e destinado a obter grande sucesso: as cartas, que se fazem cada vez mais edificantes. Excepcionalmente, temos o relato de um colono, e no finzinho do século, o olhar curioso da Inquisiģão na Bahia e em Pernambuco.

Os índios do Brasil são, no século XVI, os do espaço atribuído a Portugal pelo Papa no Tratado de Tordesilhas, ele próprio incerto em seus limites, algo entre a boca do Tocantins a boca do Parnaíba ao norte até São Vicente ao sul, talvez um pouco além se incluirmos a zona contestada dos Carijós. Os índios do rio Amazonas, na época sobretudo um rio "espanhol" , não contribuem propriamente para a formaçáo da imagem dos índios do Brasil. Essa imagem é, fundamentalmente, a dos grupos de língua Tupi e, ancilarmente, Guarani. Como em contraponto, há a figura do Aimoré, Ouetaca, Tapuia, ou seja aqueles a quem os Tupi acusam de barbárie.

\section{Primeiros Olhares}

Os portugueses, fascinados pelo Oriente, pouco especularam sobrc o Novo Mundo. Nem objeto de conhecimento ou reflexão, nem sequer ainda de intensa cobiça, o Brasil passou em grande parte despercebido durante os primeiros cinquenta anos de seu contato. Camóes

\footnotetext{
* Manuela Carneiroda Curnba é professora do Departamento de Antropologia da Faculdade de Filosofia, Letras e Ciências Humanas da USP. É autora de Antropologia do Brasil - Mito, História a Etricidade (Sāo Paulo, Brasiliense/Edusp, 1986).
} 
dedica-lhe quatro magros versos - evocando o pau brasil - no último canto dos Lusíadas (estrófe 1086, v. 138-141), publicados em 1572, e até o espanhol Ercilla falará mais dos brasileiros do que o poeta português. É só na década de 1570 que Gandavo escreve seu Tratado da Terra do Brasil (circa 1570) e sua História da Província de Santa Cruz (1576); obras provavelmente de incentivo à imigraçăo e a investimentos portugueses, semelhantes às que, bem mais cedo, os ingleses haviam feito para a Virgínia. No prólogo à História da Provncia de Santa Cruz, Gandavo fala do "pouco caso que os portugueszes fizeram sempre da mesma provincia" e diz que "os estrangeiros a tem noutra estima, e sabem suas particularidades melhor $e$ mais de raiz que nós" (p.76). Todo o interesse, todo o imaginário português se concentra, à época, nas índias, enquanto espanhóis, franceses, holandeses, ingleses, estáo fascinados pelo Novo Mundo, cada qual aliás, a partir de regióes específicas: a América dos Espanhóis é antes de tudo o México e o Peru, a dos ingleses, a Flórida, e a dos franceses é sobretudo o Brasil (N.Broc 1984: 159).

A primeira carta sobre o Brasil, a belíssima carta de 1500 , escrita por Pero Vaz de Caminha a El-Rei Dom Manuel, fica inédita e soterrada até 1773 nos arquivos portugueses. São as cartas de Américo Vespucci - as autênticas e as apócrifas - talvez por serem endereçadas a Lourenço de Medici e, através dele, ao público letrado europeu, que notabilizaram a então Terra de Vera Cruz e seus habitantes.

Por mais exatas que sejam (e certamente são mais escrupulosas do que muitos relatos posteriores), as primeiras cartas já se assentam em ideias propagadas desde o Diário da Primeira viagem de Colombo, elas próprias enraizadas nos relatos de viagens - reais ou imaginárias de Marco Polo, de Mandeville, do Preste João: idéias de Paraíso terreno e de fonte da juventude à sua proximidade, de Amazonas e de seus tesouros, mitos de origem medieval ou clássica que povoam o imaginário dos "descobridores" (1), e que se insinuam nas mais verazes descriçóes. Os viajantes vêem por indícios e ouvem dos índios, sabe-se lá em que língua, o que a Europa procura e antecipa: seus relatos, confrontados às tradições clássicas, são por sua vez sistematizados por cosmógrafos - como Pedro Mártir, o milanês, que escreve em Sevilha - que, em pouco tempo, estabelecem um corpo canônico de saber sobre o novo mundo, realimentador da observaçáo. Terão vida particularmente longa as primeiras notícias de Colombo sobre a inocência, a docilidade, a ausência de crenças da gente que encontrou, elaboradas, segundo Gerbi (1978(1975):27-28), para

(1) Uma excelente análise desses antecedentes e de sua repercussão encontra-se no livro clássico de Ś́rgio Buarque de Holanda, Visão do Paraíso (1977 (1958)). 
A primeira carta sobre o Brasil, a belissima carta de 1500 , escrita por

Pero Vaz de

Caminha a El-Rei Dom Manuel, fica inédita e soterrada até 1773 nos arquivos portugueses.

convencer os Reis Católicos da facilidade de se dominarem terras táo prodigiosamente férteis e ricas de ouro e especiarias.

A carta de Pero Vaz de Caminha é, na verdade, um diário, que registra de 22 de Abril a 10 de Maio de 1500, uma progressiva descoberta dos homens (desde o primeiro instante, não há dúvida de que são homens) e das mulheres de Porto Seguro. A primeira imagem, a mesma que Colombo tivera nas antilhas, é de que todos vão nus e sáo imberbes:

" bomens pardos, todos nus, sem nenbuma coisa que lhes cubrisse suas pergonbas, traziam arcos nas mãos e suas setas" (P.V.Caminha 1968 (1773):21). E Caminha compraz-se em um jogo de palavras e em uma primeira comparação, dizendo das moças que tinham " suas vergonhas tão altas, tão serradinbas e taio limpas de cabeleiras que, de as nós muito bem olharmos, não tinbamos nenhuma pergonba" (P.V.Caminha, ibidem: 36-7). E, mais adiante, dirá de outra índia que era "sua vergonba (que ela não tinba) tão graciosa, que a muitas mulberes da nossa terra, vendo-lhe tais feifōes, fizera vergonha, por não terem a sua como ela" (ibidem: 40).

A essa imagem de nudez que será retomada, com menos talento literário, por Vespucci (2), associa-se a idéia de inocência (p.25, 91). Caminha, com aparente candura, contrasta a ingenuidade comercial e a confiança inicial destes homens que, desde o primeiro dia, se estendem e dormem no convés do navio, com a deslealdade, a cupidez e a sede de ouro e prata dos portugueses (pp.27,30,53,49,66,76). Esses homens são formosos, gordos e sadios, como as "alimárias monteses às quais faz o ar melhor pena e melhor cabelo que às mansas". Essa idéia de não domesticação dessa gente que nada domestica - nem plantas nem animais - é, em Caminha, tăo poderosa, que o leva a ignorar a agricultura dos índios, a náo dar realce às redes $\mathrm{e}$ jangadas que menciona, e a presumir, só para ser desmentido no dia seguinte, que eles sequer tenham casas onde se abriguem (pp.81,59, 65-66). Gente "bestial" a ser amansada (pp.59,58,77,82), por quem Caminha nutre uma evidente simpatia e sobre a qual inaugura uma série de duradouros e etnograficamente duvidosos lugares-comuns: não têm chefe ou principal (sequer distinguindo o capitáo-mor que os recebe em toda a sua pompa) (pp. 46,52,27); năo têm nenhuma idolatria ou adoração (pp.90-91, 80); são uma argila moldável, uma tábula rasa, uma página em branco - "e imprimir-se-á com a ligeiresa neles qualquer cunho, que lhes quiserem dar" (p.80). Gente, em suma, que não sujeita a

(2)" Encontramas que la tierra estaba babitada de gente toda ella desnuda, as los hombres como las mujeres, sin cubrirse ninguna verguenza. Son de cuerpo bien dispuestos y proporcionados, de color blanco - Colombo dizia-os brancos também, mas Caminha dizia-os pardos e Vespucci havia dito em 1500 "de color pardo y leonado" aos habitantes do caribe - de cabellos negrosy de poca o ninguna barba" (Vespucci, Carta a Lorenzo de Medici, Lisboa, outono de 1501 in L.N. d'Olwer 1963: 541). 
natureza como não se sujeita a si mesma a jugo algum: gente montesa, gente "selvagem" (3).

Vespucci era o cosmógrafo da segunda expedição, a que Dom Manuel mandou em 1501, e que percorreu a costa durante dez longos meses, do cabo São Roque até Săo Vicente. Conta que passou 27 dias comendo e dormindo entre os "animais racionais" da Nova Terra, e é ele quem completa o inventário básico do que, daí por diante, se dirá dos índios(4). Vespucci, que fala da sua nudez, não fala mais da sua inocência: ao contrário, é ele quem relata pela primeira vez a antropofagia indígena. O retrato que faz é paradoxal: entre si, tudo têm em comum, mas vivem em guerra cruel contra seus inimigos. As razóes dessa guerra perpétua, diz Vespucci, são misteriosas já que não têm propriedade particular, já que não guerreiam para se assenhorearem de terras ou de vassalos, já que ignoram o que seja a cobiça, o roubo ou a ambição de reinar. Dizem eles apenas que querem vingar a morte de seus pais e antepassados. Fica assim introduzida a idéia de uma guerra desinteressada embora bestial e de uma antropofagia de vingança e não alimentar: distinção importante a que retornaremos mais adiante.

A ausência de propriedade e portanto de cobiça e de herança são elementos novos que Vespucci acentua. É Vespucci também quem, pela primeira vez - resquício do mito da fonte da juventude? - fala da longevidade dos brasileiros: "Son gente que vive muchos anôs, porque seguin sus descendencias conocimos muchos hombres que tienen hasta la cuarta generación de nietos. No saben contar los dias ni el año ni los meses, salvo que miden el tiempo por meses lunares, y quando quierem mostrar la edad de alguna cosa lo muestran con piedras, poniendo por cada luna una piedra, y encontré un hombre de los más viejos que me señaló con piedras haber pipido 1700 lunas, que me parece son 130 años, contando trece lunas por año" (Vespucci, Carta a Lorenzo de Médici, Lisboa, outono de 1501 in L.N.d'Olwer 1963: 542) (5). De resto, com pequenos

(3) Caminha não usa a palavra "selvagem". O termo é usado pelos franceses Thévet e Léry, e é glosado por Montaigne: "ils sont saupages, de mesme que nous appellons saurnges les fruicts que nature, de soy ot de son progres ordinaire, a produicts: là, où à la plritt, ce sont cetux que nous apons alterez par nostre artifice at detourmez de l'ordre commun, que nous dervions appeller plutost sautwnges (Montaigne 1952 (1580): 234). Inversão típica que Rousseau rctomará: a selvageria năo antecede a civilizaçāo, ao contrário, é seu produto, enquanto corrupção e desvio do curso espontâneo da natureza.

(4) A palavra índios é aqui usada anacronicamente: ela parece começar a ser empregada por meados do século aparentemente para designar os indigenas submetidos (seja aldeados, seja escravizados), por ocasião ao termo mais geral "gentio" que designa os indígenas independentes. Caminha e Vespucci dizem "gente", "homens" e "mulheres". Ao longo do século, usar-se-ão para designar as etnias os termos "geraçōes", "naçōes" e "linhagens". Pela metade do século, começar-se-á também a empregar a expressão " negro da terra" por escravo - além dos termos tradicionais "gentio", "brasil" e " brasileiro" .

(5) Até Jean de Léry (1972 (1578): 73) ainda se fala da longevidade dos brasileiros. 
acréscimos sobre costumes matrimoniais não necessariamente corretos (mas também com boa descriçăo de casas, redes e adornos), Vespucci repete a Caminha: essa gente não tem lei, nem fé, nem rei, não obedece a ninguém, cada um é senhor de si mesmo. Vive secundum naturam e não conhece a imortalidade da alma (6).

Está assim formado o lastro de uma concepçáo dos brasileiros que vigorará, com poucos retoques, entre os que praticarem o escambo de pau-brasil, papagaios, macacos e outras riquezas, ou seja entre os portugueses, até 1549, e entre os outros europeus, até muito mais tarde. Os sucessivos navios de várias nacionalidades e os intérpretes normandos ou degradados portugueses aqui estabelecidos devem ter consolidado esse saber, de tal forma que, em 1519, o italiano Antonio Pigafetta, de passagem na expedição de Fernão de Magalhães, fornece já algo como um "dictionnaire des idées reçues" sobre o Brasil do início do século XVI . Condensado, já tudo está lá: brasileiros e brasileiras vão nus, vivem até $\mathbf{1 4 0}$ anos, "não são cristãos mas também não são idólatras, porque não adoram nada" , comem a seus inimigos, tecem redes, fazem canoas, moram em grandes casas,...(A.Pigafetta 1985(1524?):57 ss.).

É somente a partir da década de $\mathbf{5 0}$ que o conhecimento do Brasil se precisará, e agora de maneiras divergentes. Teremos duas linhas divisórias básicas: uma que passa entre autores ibéricos, ligados diretamente à colonizaçăo - missionários, administradores, moradores - e autores não ibéricos ligados ao escambo, para quem os índios são matéria de reflexão muito mais que de gestão; a outra que separa, nesse período de intensa luta religiosa, autores usados por protestantes de autores usados por católicos.

Nesta última categoria, temos o detestável, pedante, condescendente e - segundo o huguenote Léry - mentiroso, franciscano André Thévet, que afirma ter visto o que năo viu, ter estado onde náo esteve $e$ preenche suas lacunas com fastidiosos e desconexos exemplos clássicos para cada uma das instituiçóes descritas (7). Contrapondo-se a Thévet,

(6) Os jesultas, por motivos teológicos e jurídicos, prestarāo grande atençāo, meio século mais tarde, aos usos matrimoniais e às crenças dos índios. Sua busea, como veremos, vai no sentido de encontrar, pelo menos em embriảo, instituiçóbs ou crenças sobre a qual possam se assentar costumes cristäos: săo eles que atestam, contrariando Vespucci, a crença tupi na imortalidade da alma.

(7) Thévet conseguiu, com tudo isso, uma consagraçäo invejável: nomeado "cosmógrafo do rei", conservador do "Cabinet do rei", ou seja um museu de curiosidades, ele foi comparado por Ronsard a Ulisses, aliás mais do que Ulisses, por ter visto e por ter escrito o que viu: "Ainsi tu as sur luy un doubled 'apantage, C'est que tu as plus peu, et nous a ton poyage Escrit de ta mnin propre et non pas luy du sien " (apud N.Broc 1984: 153). Mas Montaigne não se ilude e publica, nos seus "Canibais", um trecho ferino provavelmente dirigido a Thévet, preferindo-lhe seu próprio informante, o normando seu empregado que havia passado de dez a doze anos na França Antártica. - Ainvi je me 
direta ou indiretamente, temos também dois autores excepcionais que estiveram entre os Tupinambá mais ou menos na mesma época, mas em posiçóes simétricas, um como inimigo destinado a ser comido, outro como aliado: 0 artilheiro do Hesse, Hans Staden, que viveu prisioneiro dos Tupinambá, e os descreve como inteligência e. pragmatismo em livro publicado originalmente em 1557 que conheceu imediato sucesso - quatro ediçóes em um ano -, e o calvinista Jean de Léry que passa alguns meses, em 1557, com os mesmos Tupinambá quando a perseguiçăo que Villegagnon move aos huguenotes os obriga a se instalarem em terra firme. O livro de Léry só é publicado em 1578, e embora o autor afirme que o redigiu em 1563, várias passagens atestam interpolaçóes posteriores a esta data. Seja como for, a edição em 1592, em Francforte, da terceira parte da Coleçáo de Grandes Viagens ilustrada pelo ourives, gravurista e propagandista huguenote Theodor de Bry, que reunia os livros de Hans Staden e de Jean de Léry, publicados simultâneamente em alemão e em latim, consagra a influência desses autores fundamentais. Também republicado alguns anos mais tarde por Bry, provavelmente por atestar os péssimos hábitos dos conquistadores espanhóis, que chegam, entre outras coisas, a devorar enforcados, quando a fome os aperta em Buenos Aires, está o mercenário alemão Ulric Schmidel, que passou vinte anos perambulando pelo rio Paraguai a partir de 1537, e que fornece uma espécie de roteiro gastronômico das múltiplas etnias por que passou, entre os quais os carijós.

\section{O Teu e o Meu}

Um dos traços que mais será celebrado nesse contexto sobretudo por Jean de Léry $E$, sem dúvida, o da suposta ausência de propriedade material e de cobiça, com sua crítica explícita a sociedades movidas pelo lucro e pelo entesouramento (p.ex. J.de Léry 1972 (1578): $125-126,180,230)$. Não que os Tupinambá não desejassem bens materiais, e todo o comércio baseava-se nesse desejo: simplesmente não acumulavam, não transmitiam a herdeiros e entre si partilhavam a comida (H.Staden 1972(1557): 167, A.Thévet 1972(1558) (:144). "Ttm estes Tupinambdis uma condignio muito boa para frades franciscanos, escreverá Soares de Sousa (1971 (1587):313) que neste ponto concorda com os autores nảo ibéricos, porque o seu fato, e quanto tém, \& comum a todos os da sua casa que querem usar dele; assim das ferramentas que to o que mais estimam, como das suas roupas se as $t \mathrm{tm}$, e do seu mantimento; os quatis, quando estito comendo, pode comer com eles quem quiser, ainda que seja contratrio, sem tho impedirem nem fazerem por isso carranca"

contente de cette infurmation, sans m "enqutrir de ce les cosmographes en disent (Montaigne 1952(1580): 233-234). 
Desde Caminha e Vespucci, e, já vulgarizada a idéia, em 1515 na Nova Gazeta Alemã (apud S.B.de Holanda 1977(1959): 106), menciona-se com certa ambivalência - seria o éden? seria a barbárie? a ausência de jugo político e religioso entre os brasis. A idéia tornar-se lugar-comum ao longo do século (p.ex. Thévet 1978(1558): 98,), mas ganha com Gandavo uma forma canônica em que palavras e coisas se confundem: "A lingua deste gentio toda pela Costa be, buma: carece de tres letras - scilicet, não se acha nella $F$, nem $L$, nem $R$, cousa digna de espanto, porque assi náo tem Fé, nem Lei, nem Rei; e desta maneira vivem sem Justiga e desordenadamente." (P.M.Gandavo 1980 (1570): 52). Uma década e meia mais tarde, Gabriel Soares de Sousa retoma a fórmula de Gandavo com particular graça: "Faltam-lhes tres letras das do $A B C$, que são $F, L, R$ grande ou dobrado, coisa muito para se notar; porque, se nāo $t e m$ F, é porque não têm fé em nenbuma coisa que adorem; nem nascidos entrre os cristäos edoutrinados pelos padres da Companbia tem fé em Deus Nosso Senbor, nem tem verdade, nem lealdade e nenbuma pessoa que thes faca bem. E se não tem $L$ na sua pronunciacăo, é porque nă

Colombo, ao opor os pacificos antilhanos aos caribes insulares que os devoram, permite uma primeira localizaçāo americana desse fantasma tem lei alguma que guardar, nem preceitos para se governarem; e cada um faz lei a seu modo, e ao som da sua vontade; sem haver entre eles leis com que se governem, nem tem leis uns com os outros. $E$ se não tem esta letra $R$ na sua pronunciafão, é porque não tém rei que os reja, e a quem obedefam, nem obedecem a ninguém, nem ao pai of filho, nem of filbo ao pai (sic), e cada um vive ao som da sua pontade; para dizerem Francisco dizem Pancico, para dizerem Lourenfo, dizem Rorenfo (sic), para dizerem Rodrigo dizem Rodigo (sic); e por este modo pronunciam todos os vocábulos em que entram essas tres letras"(G.S.de Sousa 1971 (1587) :302).

$\mathrm{Na}$ França, onde os mercadores normandos continuam prosperando com o comércio de pau-brasil obtidos por escambo com os Tupinambá, essa carência de letras e de jugos náo preocupam, mas ao contrário fazem sonhar. Ronsard, em sua "Complainte contre Fortune" de 1559, fala dessa América da Idade do Ouro para onde deseja ir.

"Où le peuple incognu

Erre innocemment tout farouche et tout nu

$D$ habis tout aussi nu qu il est nu de malice

Qui ne cognoist les noms de vertu, ny de pice,

De Stnat, ni de Roy, qui vit à son plaisir,

Porté de l'apétit de son premier désiv"

O Brasil e os brasileiros estáo lá em tão alta estima que, em 1550, quando o rei Henrique II e a rainha Catarina de Médicis fazem sua entrada triunfal em Ruão, é-lhes oferecida uma festa brasileira. Yara a 
circunstância, trezentos figurantes, entre verdadeiros índios de trazidos à França, marinheiros normandos e prostitutas, todos despidos à moda Tupinambá, representam cenas de caça, de guerra, de amor, e até de abordagem a um navio português. Os choupos são pintados e carregados de bananas, papagaios e macacos são soltos no arvoredo (F.Denis 1851). O Brasil é o paraíso terreal.

\section{Cães, Canibais}

Paradoxalmente, a outra imagem que se vulgariza, $e$ que se torna emblemática do Brasil é a dos índios como canibais. Em 1540, por exemplo, o mapa de Sebastian Munster, na Geografia de Ptolomeu publicada em Basileia, coloca laconicamente, no espaço ainda largamente ignoto entre a boca do Amazonas e a boca do rio da Prata, a palavra Canibali, e a ilustra com um feixe de galhos de onde pendem uma cabeça e uma perna (Schwartz e Ehrenberg 1980, p.50, pl.18 e p.45)." Sáo câis em se comerem e matarem". escreverá Nóbrega (Nóbrega in Leite vol.II:321), implicitamente evocando a assimilação que o Renascimento fez entre canibais e cinocéfalos, homens com cabeça de cães, cómo explica Rabelais no seu glossário do Quarto Livro de Pantagruel: "Canibales, peuple monstrueux en Afrique, ayant la face comme chiens et aboyant au lieu de rire" (Rabelais 1955(1552): 737). Os canibais são, na verdade, um fantasma, uma imagem, que flutua por muito tempo no imaginário medieval sem lograr ser geograficamente atribuído. Colombo, ao opor os pacíficos 


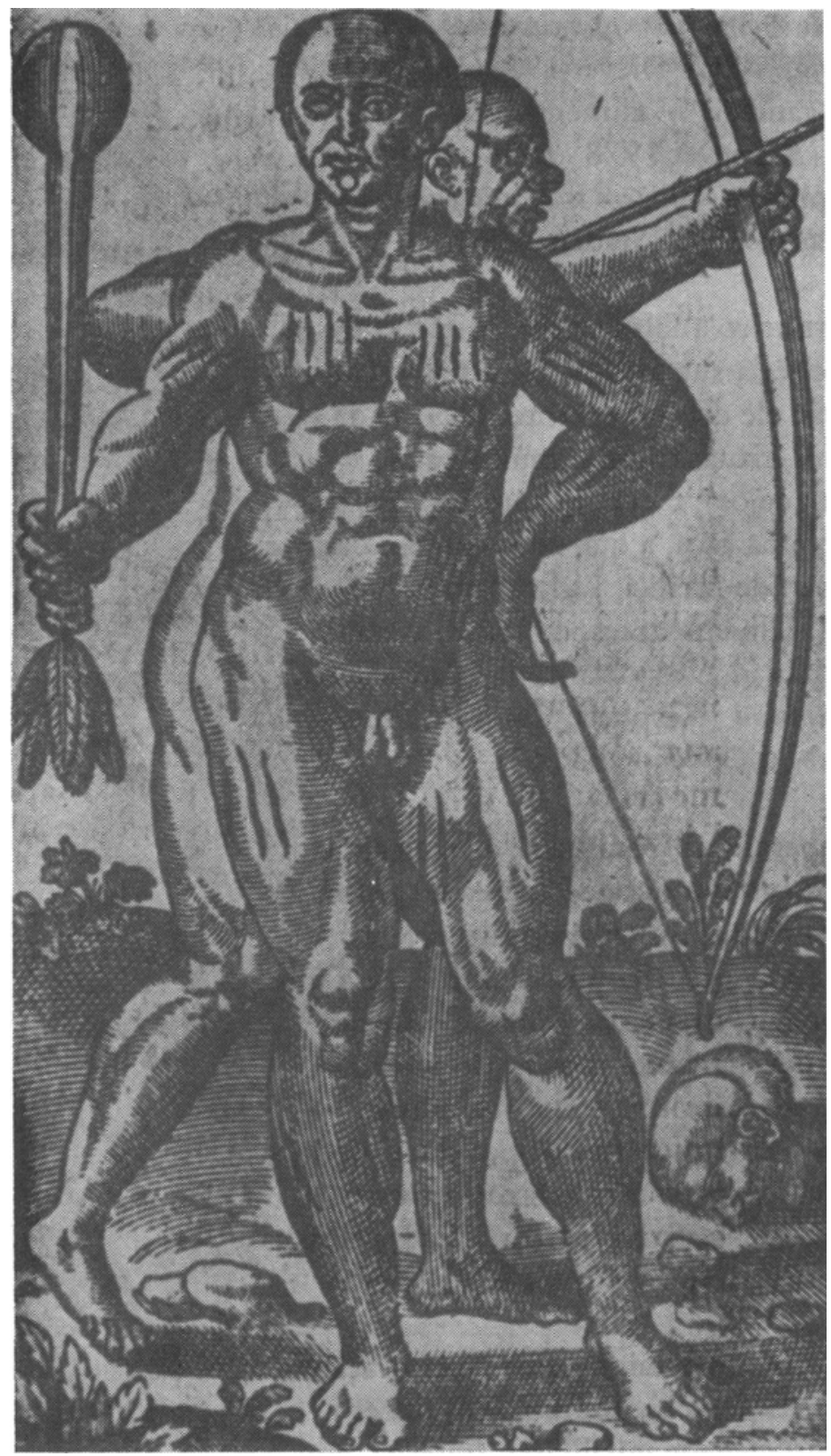

antilhanos aos caribes insulares que os devoram, permite uma primeira localização americana desse fantasma, assimilando caribes e canibais numa sinonímia que irá perdurar, no século XVIII, até à Enciclopédia (8).

\section{Antropófagos Mas Năo Canibais}

Os Tupi, no entanto, não são canibais, e sim antropófagos: a distinção que é, num primeiro momento léxica, e mais tarde, quando os termos se tornam sinônimos (9), semântica, é crucial no século XVI, e é ela quem permitirá a exaltaçáo do indio brasileiro. A diferença é esta: canibais são gente que se alimenta de carne humana; muito distinta é a situaçáo dos tupi que comem seus inimigos por vinganga.

É assim que Pigafetta distingue os brasileiros que são antropófagos, dos canibais, imediatamente ao sul (A.Pigafetta 1985 (1524?). Thévet

que assimila canibais, caribes insulares das Antilhas e possivelmente os caetés ou os potiguaras, escreve: "Os canibais, cujas terras väo do Cabo de Santo Agostinho ìs proximidades do Marinhio, sẫo os mais crutis e desumanos de todos os popos americanos, naio passando de uma canalba

(8) Overbete " canibais" na Grande Encycloptdie figura com a seguinte redaçáo: " carnibales - poyez Caraibes ou Cannibales: Saundoges insulaires de l'Ambrique qui possedent une partic

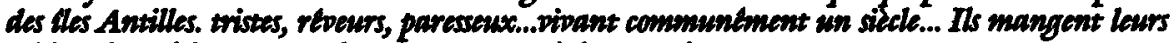

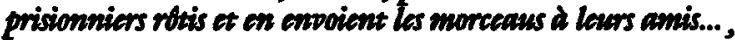

(9) Segundo Michele Ducher (1977:38); a sinonímia entre canibais e antrop6fagos vulgariza-se a partir de Montaigne. Mesmo depois de assimiladas as duas palavras, porém, a diferença que encerravam permanece, com a mesma conotaçäo moral. 
babituada a comer carne bumana do mesmo jeito que comemos carne de carneiro, se nuio até com maior satisfafá" (A.Thevet 1971(1558): 199). Thevet chega a declarar que os "canibais" alimentam-se exclusivamente de carne humana (A.Thevet 1978 (1558): 100). Mas os Tupinambá, se comem aos inimigos, "fazem isto, nao para matar a fome, mas por hostilidade, por grande dadio" (H.Staden: 176).

Quanto a Americo Vespucci, o primeiro a falar da instituição entre os tupi, uma leitura desatenta que poderia sugerir que ele esteja relatando uma antropofagia alimentar. O que ele diz, no entanto, falando da dieta variadíssima dos índios (ervas, frutas ótimas, muito peixe, mariscos, ostras, camaróes e caranguejos), é que, quanto à carne, por não terem cachorros que os ajudem na caça, a que mais comem é carne humana (Vespucci, Carta a Lorenzo de Medici, Lisboa, outono de 1501 in L.N.d'Olwer 1963: 542). Um ano antes, em outra carta, relatando sua viagem à ilha da Trinidad, Vespucci havia falado, aí sim, dos canibais que vipem de carne bumana (Vespucci, Carta a Lorenzo de Medici, Sevilha, 18.07.1500 in L.N.d'Olwer 1963: 43).

A antropofagia, nisso năo se enganaram os cronistas, é a Instituiçăo por excelência dos tupi: é ao matar um inimigo, de preferência com um golpe de tacape, no terreiro da aldeia, que o guerreiro recebe novos nomes, ganha prestígio político, acede ao casamento e até a uma imortalidade imediata. Todos, homens, mulheres, velhas e crianças, além de aliados de outras aldeias, devem comer a carne do morto. Uma única exceção a esta regra: o matador nâo come sua vítima. Comer é o corolário necessário da morte no terreiro, e as duas práticas se ligam: "Nto se tem por vingados com os matar sincio com os comer" (A.Blasquez a Loyola, Bahia, 1557 in Navarro e outros, 1988, p.198). Morte ritual e antropofagia são o nexo das sociedades tupis (10).

São esses canibais que conheceráo com Montaigne uma consagraçáo duradoura. Tornam-se a má-consciência da civilizaçáo, seus juízes morais, a prova de que existe uma sociedade igualitária, fraterna, em que o Meu não se distingue do Teu, ignorante do lucro e do entesouramento, em suma, a da Idade de Ouro. Suas guerras incessantes, náo movidas pelo lucro ou pela conquista territorial, são nobres e generosas. Regidos pelas leis naturais, ainda pouco abastardas, estăo próximos de uma pureza original e atestam que é possível uma sociedade com "peu d'artifice et de soudeure humaine" . Em uma passagem que Shakespeare retomará na sua Tempestade,

(10) Há uma extensa literatura a respeito da morte guerreira e do canibalismo Tupinambá, instituiģáo central dessa sociedade. Para análises, vejam-se por exemplo Métraux 1967(1928), Fernandes 1963(1949), Clastres 1972, Cunha e Castro 1986. 
Montaigne resume essas virtudes: "C'est une nation... en laquelle il $n$ 'y a nulle espèce de trafique; nulle cognoissance de lettres; nulle science des nombres; nul nom de magistrat, ny de supériorite politique; nul $x$ usage de service, de richesse ou de pauprett; nuls contrats; nulles successions; nuls partages; nulles occupations qu'oysipes; nul respect de parenté que communnuls vestemens: nulle agriculture: nul mettal; nul usage de vin ou de bled. Les paroles mesmes qui signifient le mensonge, la trabison, la dissimulation, l'aparice, l'envie, la détraction, le pardon, inouies" (Montaigne 1952(1580): 235-236) (11). Até sua culinária é sem artifícios! Este resumo das virtudes dos canibais, com seus lapsos evidentes - a agricultura por exemplo, existe entre os Tupis (12) - não é um discurso de etnólogo e sim de moralista, e como tal deve ser entendido: constitui o advento de uma duradoura imagem, a do selvagem como testemunha de acusaçáo de uma civilização corruptora e sanguinária. Não é fortuíto que Montaigne, no fim de seu ensaio, mencione as objeçōes que ouviu de três índios brasileiros com quem o rei Carlos IX (que entrava em Ruão, em 1562, após a rebelião e a subjugaçăo da cidade), conversou. Estranhavam que homens feitos obedecessem a uma criança - o rei. E estranhavam que existissem na mesma sociedade ricos e mendigos (Montaigne, ibidem: 243-4).

\section{Semelhanças, Dessemelhanças}

Procuram-se de um lado, semelhanças, continuidades. Os índios são humanos, ninguém que os tenha visto o pöe em dúvida no século XVI: a bula de Paulo III em 1534 serve menos provavelmente para dissipar dúvidas a respeito do tema do que para reivindicar a

(11) Compara-se a versão de Shakespeare (datada de 1611), na tirada de Gonzalo na "Tempestade" (ato II, cena I):

"I'the commonewealth I would by contraries Execute all things; for no kind of traffic Would I admit; no name of magistrate; Letters should not be known; riches, poperty, And use of service none; contract, succession, Bourn, bound of land, tilth, vincyard, none; No use of metal, corn, or pine, or oil; No occupation; all men, idle all;

And women too, but innocent and pure;

No soperaignty ...

All things in common nature should produce

Without supeat or endeapour: treason, felony Sword, pike, knife, gun or need of any engine,

Would I not bape; but nature should bring forth, Of its onon kind, all foison, all abundance, To fred my innocent people."

(12) Essa "primitivizaçáo" do tupi, com eliminaçấo sistemática da referência à sua agricultura percorre o século XVI: Pero Vaz de Caminha poderia não tê-la observado nos curtos dias que passou na costa, mas Vespucci e Pigafetta nāo a mencionam rampouco. Mais deliberadamente ainda, as gravuras com que Theodor de Bry ilustra o relato de Hans Staden omitem detalhes de agricultura que figuravam nas xilogravuras em que se inspirou, como observa B.Bucher (1977: 56). 
jurisdição da Igreja sobre uma parcela do globo. Com o Novo Mundo descobre-se também uma Nova Humanidade. Resta o problema crucial de inseri-la na economia divina o que implica inseri-la na genealogia dos povos. Para isso, não há outra solução senão a da continuidade, senão abrir-lhe um espaço na cosmologia européia. Por que a humanidade é uma só, os habitantes do Novo Mundo descendem necessariamente de Adáo e Eva, e portanto de um dos filhos de Noé, provavelmente do maldito, Cam, aquele que desnudou seu pai - razáo, especula Nóbrega, da nudez dos índios -; como camitas e descendentes de Noé, os Tupi da costa guardariam aliás uma vaga lembrança do dilúvio - " sabem do dilúvio de Noé, bem que não conforme a verdadeira história" (Nóbrega 1988(1549): 91) -, suficiente no entanto, para atestar sua origem (13). E por que não poderiam ter ficado à margem da Boa Nova, teriam sido visitados pelo apóstolo São Tomé, que seria lembrado (e cujas pegadas Nóbrega teria ido ver em 1549, na Bahia, gravadas na pedra) sob o nome levemente deturpado de Sumé ou Zomé (Nóbrega 1988 (1549): 78,91,101) (14). Há aí, claramente, toda uma problemática de confluência, em que a mitologia tupi de Sumé e do dilúvio é interpretada como vestígio, confuso e distorcido, de uma origem e de um conhecimento comuns à humanidade. A essa reciclagem do mito de Sumé, já evocada desde 1515 na Nova Gazeta Alemá (15), e que visa tornar inteligível e teologicamente aceitável para os jesuítas uma situação totalmente inédita, corresponderá, por parte dos índios, uma tentativa análoga de achar lugar para os recém-chegados em sua cosmologia, assignando-lhes inicialmente o lugar de caraíbas, ou seja de profetas (Thévet 1978 (1558): 100), que Hans Staden saberá usar, quando prisioneiro dos Tupinambá, para salvar a pele.

Por outro lado, na França e, mais como eco, na Inglaterra, as viagens ou melhor, os relatos de viagens, darão início a uma reflexáo humanista sobre a dissemelhança. Nota-se porém que pressuposto básico, aqui também, é uma similitude suficiente para garantir a comparabilidade: pois a reflexáo renascentista é muito menos uma tentativa de. compreender o outro do que de se ver a si mesmo "em perspectiva" , de se compreender a si mesmo em um mundo cuja

(13) Sobre a lembrança e as versóes do dilúvio, vejam-se entre outros H.Staden 1974 (1557): 174, J. de Léry 1974(1578): 165-6, A.Thévet 1953(1575): 39-40, 43-45.

(14) O mito missionário de Sumé e, no Perú, de Pay Tumé, amplia-se como bem observa Sérgio Buarque de Holanda em estudo magistral que the explicita as rázes eos desdobramentos, quando passa para as colônias espanholas. No Brasil, avalia Sérgio Buarque, a história "não passa, se tanto, de um mito vagamente propedêutico" (S.B.Holanda 1977: 125).

(15) Esse relato (Neue Zeirung), publicado em 1515 e baseado em expediçăo de ano anterior, já menciona entre os brasis e a "recordaçäo de São Tomén, suas pegadas e suas cruzes, expandindo assim a lenda de São Tomé, originalmente apóstolo das índias Orientais (S.B.Holanda 1977(1959): 104 ss.). 
Os índios são

humanos, ninguém que os tenha visto o põe em dúvida no seculo XVI

ordem, com as guerras de religiāo, passou a ser relativa. $O$ "selvagem" que Jean de Léry póe em cena e que é um dos únicos personagens "falantes" do século, por mais real que seja sua fala - e a tradução interlinear que Léry fornece do diálogo atesta sua veracidade - é, náo obstante, figura de retórica, contraponto positivo de todos os horrores que o huguenote perseguido que denunciar em sua França natal (Fr.Lestringant 1983). Shakespeare com seu infame Caliban, anagrama de canibal e táo retórico quanto o Tupinambá de Léry, só inverte os valores, sem inverter os personagens e cria assim um anagrama semântico ao índio de Montaigne.

Nos jesuítas, no entanto, preocupados com a gestão das almas, a dissemelhança é assunto de outro tipo de reflexão, náo sobre si mesmo, senão sobre o estatuto do alheio. Reflexão cuidadosa de quem não se pode deixar enganar, e que imputa à semelhança um caráter ilusório. Ilusão que provem do grande deceptor, o Demônio, que faz da semelhança um arremedo: as santidades, santos ou caraíbas, profetas tradicionais que assumem, no processo colonial, aspectos milenaristas, são obra de inspiração sua (F.Cardim 1980: 87-88, Nóbrega aos Pes. de Coimbra, Baía, agosto de 1549 in S.Ieite vol.I: 150-151). Há nas santidades uma competiçáo implícita pela liderança espiritual e material. Mas há também um esforço notável, simétrico ao dos missionários, de abranger o dissemelhante, de incorporar e tornar inteligíveis os estrangeiros e suas crenças.

Colocada sob suspeita e passada ao crivo dos valores que encerra, a semelhança passa a não ser percebida: em 1554, dois irmáos da Companhia, Pero Correia e Joáo de Souza, sáo mortos a frechadas pelos Carijós, que teriam sido incitados por um espanhol. Os irmăos, relata Anchieta de segunda máo, aceitam seu martírio com força de alma: todos os missionários anseiam por fecundar com seu sangue a seara de almas que está sendo plantada - o topos é recorrente, por exemplo em Anchieta e em Nóbregá. "Não foi pequena", escreve Anchieta ao relatar a morte dos irmãos a Santo Inácio de Loyola, "a consolasẩo que recebemos de morte tão gloriosa, desejando todos ardentemente e pedindo a Deus com orajóes contínuas morrer deste modo" (Anchieta a Loyola, São Vivente, fim de março de 1555 in H.Viotti org. Anchieta, Cartas. São Paulo, ed. Loyola: 98). A descriçăo e os anseios encontram paralelos claros na déscriçáo da morte ideal do guerreiro Tupi. Digna do guerreiro; só a mórte cerimonial nas măos dos inimigos, após um enfrentamento em que se ressalta a dignidade $e$ a altivez de quem vai morrer. A única sepultura almejada é o estômago dos inimigos: "Até os cativos julgam que lhes sucede nisso coisa nobre e digna, deparanido-se-lhes morte ta gloriosa, como eles julgam, pois dizem que é próprio de Animo timido e impróprio para a guerra morrer de maneira

Estudos Avanģados, 4(10) 
que tenbam de suportar na sepultura o peso da terra, que julgam ser muito grande" (Anchieta a Loyola, São Paulo de Piratininga, I de Setembro de 1554, ibidem, p.74). O trecho faz parte de carta escrita por Anchieta a Santo Inácio apenas 6 meses antes da outra, e a semelhança com o martírio dos irmãos jesuítas chama nossa atençăo, mas não a de Anchieta: mesmas cenas, mesmo ânimo, mesma crença no valor c̀e tal morte. Mas são valores diferentes, e esta diferença cega o jesuíta, incapaz de perceber a estrita semelhança entre as cenas que descreve.

\section{O Índio dos Jesuítas}

Há vários gêneros na literatura jesuítica do período,e, talvez com exceção da lírica, todos eles pedagógicos. Há as cartas a que já nos referimos, que mais do que simples relatos, são também assunto para reflexão e estudo na metrópole. Há o catecismo de Anchieta. Há o teatro, ainda de Anchieta, que pretende fornecer ao índio uma nova auto-imagem. Há por fim uma peça bastante extraordinária pelo realismo de pelo menos sua primeira parte que é o "Diálogo da Conversão do Gentio" , em que Nóbrega põe em cena as dúvidas e os preconceitos dos missionários, deixando perceber que a visáo jesuíta dos índios não é homogênea. Ele próprio, aliás, parte de uma posição humanista e letrada para chegar a um pragmatismo de administrador: comparem-se as cartas de 1549, ano da chegada de Nóbrega ao Brasil, em que louva aos índios por não entesourarem riquezas e partilharem seus bens, e por "em muitas coisas, guardarem a lei natual" (Nóbrega 1988: 100), com as cartas desencantadas dos anos subseqüentes.

\section{O "Diálogo da Conversão do Gentio" é escrito por Nóbrega na} Bahia em 1556 e 1557 póe cena dois jesuítas, que não são padres, e sim irmáos, e que representam a voz corrente entre os menos graduados da Companhia de Jesus. Um dos irmãos é pregador, outro ferreiro, e Nóbrega acaba evangelicamente dando ao ferreiro o papel de maior sabedoria. A conclusão de Nóbrega é otimista - não há por que os missionários desesperarem da conversão dos índios - mas a discussão inicial que ele imputa aos dois irmãos é reveladora de um hiato entre uma visão "vulgar" do missionário e uma versão teologicamente elaborada. O gentio não tem rei, se o tivera, poder-se-iam converter reinos, como se dera no tempo dos apóstolos, como se dava então na América Espanhola e se estava tentando no Oriente (16). A conversão portanto era, forçosamentc, de naturcza

(16) A questāo da lei e da sujeição é ponto de algumas hesitaçóes por parte dos jesuítas. Ora declaram que de nada vale serem os índios christäos por força e gentios na vida e nos costumes, ora mais frequentemente desabafam como Anchieta: "Năo se pode portanto esperar nem conseguir nada em toda esta terra na conversão dos gentios, sem 
A sexualidade indigena, como $e$ de se prever, suscitou grande interesse tanto entre cronistas filosofantes quanto entre gestores de almas.

individual. Mas os gentios careciam de fé, não adoravam coisa alguma. Como nảo se apegavam a velhos ídolos, tampouco se aferravam à nova fé:

\section{"Sabeis qual be a mor dificuldade que thes acho? Serem täm faciles de} diserem a tudo si ou pa, ou como pós quizerdes; tudo aprovaro logo, em com a mesma facilidade com que dizem pa (sim), dizem aani (não)" (Nóbrega in Leite 1954. vol. II: 322). Daí sua inconstância: "Com um anzol que thes de, os converterei a todos, com outros os tornarei a desconverter, por serem incostantes, e não lhes entrar a verdadeira fee no corafáo" (Nóbrega in Leite, vol.II, p.320). Falta aos gentios a lei que os tornaria "políticos" , membros de uma sociedade civil que thes conferiria a "razão" , estirpando-lhes a rudeza e a bestialidade em que vivem. Este diagnóstico cru de que os índios carecem de rei, de lei e de razáo é o mesmo que o Irmão Antonio Blázquez expõe sem rodeios teológicos em carta de 1555 aos irmáos de Coimbra.

\section{"O Hermanos mios en Jesú Cbristo charissimos, quántas lágrimas} derramarian puestros ojos si viéssedes estas criaturas de Dios vivir quassi a manera de pestias (quase à maneira de bestas) sin rey, sin ley y sin razón, encarnifados en comer carne bumana y tan embebidos en esta bruteza que antes consentirain perder quanto tienen que dar un negro contrario, que tienen determinado de comer (17). Entre ellos no ay amor ni lealtad. Vendense unos a otros estimando más una cunã o podón que la libertad de un sobrino o pariente más cercano que truecan por hierro, y es tanta su misseria que a las vezes se lo cambian por un poco de barina (18). No tienen a quien obedezcan sino a sus proprias voluntades, $y$ de aqui es que bazen quanto se les antoja enclinándose con ellas a vicios sucissimos y tan torpes, que tengo por mejor callarlos debaxo de silencio que escriviendo descubrir maldades tan enormes." (Ir. Blázquez, Baía, 8 de Julho de 1555, in Leite vol.II, p.252).

A este retrato negro e cheio de contradiçóes da torpeza e da bestialidade dos índios, pode-se opor o discurso ainda humanista de Nóbrega que contrasta os filósofos empedernidos da antiguidade aos índios que apenas infringem a bagatéla de dois ou três mandamentos, e de resto "entre si vivem mui amigavelmente" : Em suma, resume

virem para cá muitos cristāos, que conformando-se a si e a suas vidas com a vontade de Deus, sujeitem os índios ao jugo da escravidão $c$ os obriguem a acolher-se à bandeira de Cristo." (Anchieta a Loyola, Săo Vicente, fim de Março de 1555, in Leite, vol.II, p.207). Nóbrega acaba por optar pela sujeição, que é posta em prática pelo governador Mem de Sá.

(17) Referencia à resirência dos índios a venderem como escravos àos portugueses os prísioneiros destinados a serem ritualmente mortos em terreiro.

(18) Esta passagem, que parece contradizer a frase anterior, é uma referência à questāo de venda de si mesmo e dos seus filhos em escravidăo, praticada em momentos de penúria, e que deu origem a uma discussāo jurídica em que os jesuítas tomaram parte (vide Cunha 1986(1985)). 
Nóbrega, " sua bem-aventuranfa é matar e ter nomes, cesta é sua glória por que mais fazem. A lei nalural, não a guardam porque se comem; são muito luxuriosos, muito mentirosos, nenbuma coisa aborrecem por má, e nenbuma louvam por boa;tem crédito em seus feiticeiros". Eis tudo. (Nóbrega in Leite vol.II,p.344-345).

Sem fé, mas crédulos: os jesuítas imputam aos índios uma extrema credulidade, e a coisa é só aparentemente contraditória. No fundo, a fé é a forma centralizada da crença, excludente e ciumenta. A carência de fé, de lei, de rei e de razáo política não são senão avatares de uma mesma ausência de jugo, de um nomadismo ideológio que faz pendant a atomização política. A credulidade é uma forma de vagabundagem da fé. É por isso que a sujeiçáo tem de se dar em todos os planos ao mesmo tempo; nisso parecem convergir afinal tanto os jesuítas, quanto os colonos e os administradores. A sujeiçáo política é a condição da sujeição religiosa.

Seja como for, entre "feiticeiros" e jesuítas instaura-se desde cedo uma concorrência, que se trava curiosamente no terreno ora de uns ora de outros: ou seja, os jesuítas competem em curas e milagres com os xamãs, arvorando-se em xamás mais poderosos (p.ex. A.Navarro, Carta da Bahia, 1550, in Navarro 1988:76), enquanto os xamãs desafiam aos padres: um caraíba, em 1550, afirma que transformaria a todos em pássaros, destruiria a igreja e o engenho, e a lagarta das roças que os padres não destruiam, ele a eliminaria (Nóbrega a Torres, Baía 5 de julho de 1559 in S.Leite 1954, III: 53). É notável que os padres, embora muito mais céticos do que será, no século XVII, o Pe. Montoya, não contestam necessariamente aos feiticeiros a realidade de suas curas, milagres e prodígios, contestam-lhes sim a fonte desses poderes sobrenaturais que não viriam de Deus senão do Demônio.

Em demônios ou espíritos - os anbang - pelo menos, à falta de crerem em Deus, os índios acreditam (H.Staden 1974 (1557):158) e, sem grandes hesitaçóes, os europeus também (A.Thévet 1978(1558):115, J.de Léry 1972(1578): 159-60; F.Cardim: 87). De Bry, a partir de xilogravura da edição original de Jean de Léry difunde a imagem de. índios atormentados constantemente por esses demônios. E Anchieta chega a montar todo o seu teatro destinado aos catecúmenos indígenas em cima de um roteiro único, em que vários demônios (entre os quais faz às vezes irreverentemente figurar seus próprios inimigos como o Tupinambá Aimbiré que o manteve prisioneiro), tentam impedir as almas de chegarem ao céu. Numa das versōes, inspirado, Anchieta encena o ritual máximo da antropofagia tupi: um principal quebra a cabeça a um diabo - o Macaxera - e sobre ela toma novo nome Anbangupiara. ou seja inimigo de Anbang: 
Pronto! Matei Macaxera!

Já não existe o mal que era ...

Eu sou Anbangupiara!

(J. de Anchieta 1977 (1589): 244)

\section{Luxuriosos, Sodomitas}

Reencontram-se aqui as oposiçôes classicas, entre uma antropofagia nobre, de vinganca, $e 0$ apetite bestial por came humana cujo paradigma são os citas nórdicos de Hérodoto.

A sexualidade indígena, como é de se prever, suscitou grande interesse tanto entre cronistas filosofantes quanto entre gestores de almas. Jean de Léry sustenta, segundo seu uso, que, em matéria de lascívia, os europeus são piores que os brasileiros (J.de Léry 1972(1578): 177). Os costumes matrimoniais, a poliginia associada ao prestígio guerreiro, o levirato, o avunculado - ou seja o privilégio de casamento do tio materno sobre a filha da irmã - a liberdade pré-nupcial contrastando com o ciume pela mulher casada e o rigor com o adultério, a hospitalidade sexual praticada com aliados mas também com os cativos, a iniciaçáo sexual dos rapazes por mulheres mais velhas, os despreocupados casamentos e separaçóes sucessivos, tudo isto era insólito. Os jesuítas debruçar-se-ão com especial cuidado sobre estes costumes (vide p.ex. Anchieta 1846), e isto por uma razão prática: tratava-se de construir famílias cristás com os neófitos indígenas. Para tanto, era preciso reconhecer a verdadeira esposa entre as múltiplas esposas, sucessivas ou concomitantes, ou seja, a primeira que havia sido desposada com ânimo de ser vitalícia. Por outro lado, as regras de aliança dos índios contrariavam os impedimentos canônicos, e os missionários logo são levados a pedirem dispensas ao Papa dos impedimentos pelo menos de terceiro e quarto grau.

Quanto à sodomia, fazia parte dos grandes tabus europeus e, na América, parece estar sempre associada ao canibalismo, como se houvesse equivalência simbólica entre se alimentar do mesmo e coabitar com o mesmo. Essa correspondência entre homofagia $e$ homossexualismo é discernível entre outros em Michele de Cuneo, Cortés e Oviedo: significativamente, as duas acusaçóes são rechaçadas em conjunto por Las Casas (A.Gerbi 1978(1975): 48-49, 118, 412 e 424). No Brasil, sua existência, como entre os portugueses - haja vista a Inquisiçáo - é certa, mas seu estatuto moral entre os índios é incerto. Jean de Léry e Thévet mencionam-na para dizer que é reprovada pelos índios (J.de Léry 1972(1578): 174 e A.Thévet 1953(1575): 137). Os jesuítas, curiosamente, náo parecem falar dela. Mas Gabriel Soares de Sousa (1971(1587): 308), já para o firn do século, carrega nas tintas: "São os Tupinamba trio luxuriosos que ná bá pecado de luxiria que não cometam...stio muito afeifoados ao pecado nefando, entre os quais se não ttm por afronta; ...e nas suas aldeias pelo sertáo há alguns que tlm tenda puiblica a quantos os querim como mulheres puiblicas".

Estudos Avançados, 4(10) 


\section{Outras Nações de Índios}

Aos poucos vão se conhecendo, sobretudo terra adentro, outras "castas de gentio" . Pelo fim do século, Gabriel Soares de Souza e Fernáo Cardim fornecem inventários complexos destas outras etnias. Um dos atributos que é repartido entre elas é sintomático da colonização: as naçóes são leais ou traiçoeiràs, o que supóe sua inserção na rede de alianças coloniais, e deixa transparecer uma política indígena, com estratégias próprias, fazendo uso da política indigenista.

Mas, no século XVI, ainda prevalece uma visão que/adere estreitamente ao etnocentrismo tupi. Denuncia-se ássim a inaudita selvageria dos Aimorés de Porto Seguro e de Ilhéus: "São estes aimorés tão selpagens que, dos outros bárbaros são havidos por mais que bárbaros" (G.S.de Sousa 1971(1587): 79). Săo nômades, năo lhes conhecendo aldeias. Não plantam roças e vivem de caça e coleta de frutos silvestres; sua fala é travada e não é passivel de escrita. São traiçoeiros e não enfrentam os inimigos em campo aberto, senão lhes armam ciladas. Comem sua caça crua ou mal assada, omofagia que prenuncia o que constitui o paroxismo da selvageria, sua antropofagia alimentar (G.S.de Sousa, ibidem), tema crucial que tratamos acima. Distingue-se assim um canibalismo de vingança - o dos Tupi - e um canibalismo alimentar, dos bárbaros Aimorés, dos Oitacás, e alguns mais. Uns seguem à risca um ritual elaborado e se comem carne humana, " não é por gosto ou apetite que a comem" (A.Pigafetta 1985(1524?): 58) mas por vingança. Os outros apenas comem para se alimentar: "Comem estes selvagens carne bumana por mantimento, o que não tem o outro gentio que a não come senäo por vinganfa de suas brigas e antiguidade de seus ódios" (G.S.de Sousa 1971(1587): 79).

Reencontram-se aqui as oposiçōes clássicas, entre uma antropofagia nobre, de vingança, $\mathrm{e} O$ apetite bestial por carne humana cujo paradigma são os citas nórdicos de Hérodoto. A antropofagia e suas modalidades, será, no século XVI, um tema quase obsessivo e que servirá de operador para as grandes cisōes do século. Os casos de antropofagia alimentar e de crueldades inauditas durante as guerras de religião, na França, ou na conquista espanhola das Américas, sáo rememorados acusatoriamente por católicos e protestantes. De um lado como de outro, publicam-se cenas de esquartejamento e suplícios atribuídos ora a calvinistas, ora a católicos. Dentro da selvageria em que a França se encontra imersa, é como se a antropofagia Tupinambá figurasse como a forma mais civilizada dentro do gênero. Em 1500, Caminha viu "gente" em Vera Cruz. Falava-se então de homens e mulheres. O escambo povoou a terra de "brasis" e "brasileiros" . Os engenhos distinguiram o "gentio" insubmisso do "índio" e 
do "negro da terra" que trabalhavam. Os franceses que năo conseguiram se firmar na terra, viram "selvagens" .

Pelo fim do século, estão consolidadas, na realidade, duas imagens de índios que só muito tenuamente se recobrem: a francesa que o exalta, e a ibérica, que o deprecia. Uma imagem de viajante, outra de colono.

Bibliografia

ANCHIETA, José de, 1846, "Informação dos casamentos dos ndios do Brasil". Revista do Instituto Histrico e Geogrdfico Bravileiro tomo 8 n.2: 254-262.

ANCHIETA, José de, 1977 (1589), "Recebimento que fizeram os índios de Guaraparim ao Padre Provincial Marçal Beliarte" in Teatro de Ancbieta. Org.P.A.Cardoso.: 235-246. São Paulo, ed.Loyola.

ANCHIETA, José de, 1984(1553-1584), Cartas. Correspondéncia Ativa e passipa, Obras Completas 60 volume. Org.H.Viotti, São Paulo, Ed. Loyola, 504pp.

BROC, Numa 1984, "Reflets americains dans la potsie de la Renaissance", in La Renatissance et Le Nouveau Monde: 151-163. Québec, Muste du Québec.

BUCHER, Bernadette 1977, La saupage aux seivs pendants. Paris, Hermann, 272pp.

CAMINHA, Pero Vaz de 1968 (1500), Carta a El Rey Dom Manuel. Rio de Janeiro, Ed. Sabiá, 97pp.

CARDIM, Fernăo, 1980 (1625, escrito em 1584), Tratados da Terra e Gente do Brasil. Săo Paulo, Ed. Itatiaia e EDUSP, 206pp.

CLASTRES, Hélène, 1972, "Les Beaux-frères ennemis. A propos du cannibalisme Tupinamba" in Destins du Cannibalisme. Noupelle Revue de Pyychanalyse n.6: 71-82.

CUNHA, Manuela C. da e CASTRO, Eduardo V. de 1985, "Vingança e Temporalidade: os Tupinanbá" Joumal de La Socita des Ambricanistes vol. LI: 191-208.

CUNHA, Manuela Carneiro da, 1986(1985), "Sobre a servidāo voluntária: outro discurso" in Amtropologia do Brasil, Mito, bistoria, ctnicidade: 145-158. São Paulo, Brasiliense e EDUSP.

DENIS, Ferdinand, 1851, Une fite bresilienre cllebrte on 1550, suivie d'un fragment du seizitume siecle roulant sur la théogonie des anciens peruples du Brésil et des poesies en langue typique de Cbristopam Valente. Paris, Techner.

DUCHET, Michèle, 1977 (1971), Anthropologie et Histoire au Siecle des Lumizres. Paris, Flammarion, 446pp.

FERNANDES, Florestan, 1963 (1949), Organizaça Social dos Tupinambd. Săo Paulo, Dífusão Européia do Livro, 375pp.

GANDAVO, Pero de Magalhāes, 1980 (escrito circa 1570 e 1576), Tratado da Terra do Brasil e Historia da Proptncia de Santa Cruz. Săo Paulo, Ed. Itatiaia e EDUSP, 149pp.

GERBI, Antonello 1978(1975), Ia Naturaleza de las Indius Nuepas. De Cristobal Colón a Gonzalo Fermandéz de Oviedo. México, Fondo de Cultura Econômica, 562pp.

HOLANDA, Sérgio Buarque 1977(1958), Visio do Paratso. Os motipos edénicos no descobrimento e colonizanfato do Brasil. Sáo Paulo, Cia. Editora Nacional, 3a. Ed., 360pp.

LETE, Serafim, S.I. 1954, Cartas dos Primeiros Jesuttas do Brasil. Săo Paulo, 3 vols.

LESTRINGANT, Frank 1983, "Le cannibale et ses paradoxes. Images du cannibalisme au temps des Guerres de Religion". Mentalities/Mentalités vol.1 n.2: 4-19

LERY, Jean de 1972 (1578, escrito circa 1563), Viagem dè terra do Brasil. Săo Paulo, Martins Ed. e EDUSP, 251pp.

MÉTRAUX, Alfred, 1967 (1928) Religions et magies indicnnes d'Amtrique du Sud. Paris, Gallimard.

MONTAIGNE, Michel de, 1952(1580), "Des cannibales" . Les Essais.vol.1: 230-245. Paris, Garnier. 
NAVARRO, Azpicuelta e outros, 1988, Cartas Amulsas, Cartas Jesutricas 2. São Paulo, Itatiaia e EDUSP, $529 \mathrm{pp}$.

NÓBREGA, Pe. Manoel da, 1988, Cartas do Brasil, Cartas Jesutticas 1.. São Paulo, Ed. Itatiaia e EDUSP, 278pp.

OLWER, Luis Nicolau d' (org.) 1963, Cronistas de las Culturas Precolombinas. México, Fondo de Cultura Economica, 756pp.

PIGAFETTA, Antonio 1985 (1524?), A Primeira Viagem ao Redor do Mundo. O disirio da expedifaro de Fernio de Magalbates. Porto Alegre, L\&PM, 202pp.

RABELAIS, François 1955 (1552), "Briefve Déclaration d'aucunes dictions plus obscures contenues on quatriesme livre des faicts et dits héroiques de Pantagruel en l'espitre liminaires" , in Oeupres Complètes. Paris, Gallimard, Bibliothèque de la Pléiade.

SCHMIDEL, Ulrico 1986 (1587), Relatos de la conquista del RLo de la Plata y Paraguay 1534-1554 . Madrid, Alianza Editorial, 127pp.

SCHWARTZ, Seymour I and EHRENBERG, Ralph E., 1980, The Mapping os America . New York, Harry N.Abram Inc., 363pp.

SOUSA, Gabriel Soares de 1971 (1587), Tratado Descritivo do Brasil em 1587 . Săo Paulo, Cia Editora Nacional e EDUSP. 389pp.

STADEN, Hans, 1974 (1557), Duas Viagens ao Brasil .São Paulo, Ed. Itatiaia e EDUSP, 216pp.

THÉVET, André, 1978 (1558), As singularidades da Franga Antdrtica. Săo Paulo, Ed. Itatiaia e EDUSP, 27lpp.

THÉVET, André, 1953 (1575). Le Brésil et les Brtsiliens. Les Franfauis en Amerique pendant la deuxieme moitie du XVI e siecle (corresponde a La Cosmographie Uniperselle). Paris, Presses Universitaires de France, 346pp 